\title{
International Economic Sanctions, University Life, and Global Citizenship Education: The Case of Iran
}

\author{
Shadi Mehrabi \\ University of Alberta \\ smehrabi@ualberta.ca
}

\begin{abstract}
U.S. economic sanctions against Iran have been the main feature of U.S. - Iran relations since Iran's 1979 Islamic revolution (Katzman, 2013). From 2006, United Nations and European Union followed such policy against Iran, as a response to Iran's progress in its nuclear program. While the purpose of these imposed sanctions is to stop the progress of the nuclear program, there is a concern regarding the destructive effects of the sanctions on Iranian citizens' lives. The economy of a country is integral to citizens' well-being and influences people's lives in different ways. Higher education is one of the sectors that can be affected by the economic state of the country. Narrating the socio-historical background of the sanctions, this paper will argue about the role of the economic sanctions on Iranian citizens' lives, focusing specifically on students. Since economic sanctions are arguably a means of violating basic human right, i.e., education, I will propose global citizenship education as a way to counter such a violation.
\end{abstract}

Keywords: Economic Sanctions, Iran, Higher Education, Global Citizenship Education

\section{Introduction}

Higher education in Iran has always been a function of the economic and political status of the country. Any change in the political and economic status of the country results in changes in higher education arrangements. Since Iranian higher education was highly Americanized before the Islamic Revolution of 1979, one of the main goals of the revolution was to resist Mohammad Reza Shah's policies of Americanization of Iran. Criticizing Mohammad Reza Shah's international policies, Ayatollah Khomeini identified the U.S. as one of the main enemies of Iran. Since the revolution, Iran has been trying to enhance the quality of education and to expand its higher education system, but taking this stance against the U.S. has positioned its 
universities in global isolation. Moreover, the economic, social and political situations of the country have resulted in many difficulties for students in universities. In response to such pressures, many students leave the country to benefit from a context in which there is less political and social tension. In 1999, pointing to the 15 percent drain of highly educated citizens annually, the International Monetary Fund (IMF) stated that the outflow of highly educated individuals is a phenomenon that policymakers cannot ignore. Although international media and propaganda attribute such a problem to internal political pressure, student life within Iran is highly affected by international economic sanctions, mainly driven by the United States (U.S.).

The ideological clashes between Iran and the U.S. led to U.S.-driven economic sanctions against Iran following the Islamic revolution. As Peksen (2009) states, "The ideal goal of sanctions has been to apply economic and diplomatic pressure on target countries to induce the target political leadership to comply with sender countries' demands" (p. 59). While in the beginning, the aim of U.S. sanctions was to restrict the relations between two countries, later, other rounds of U.S.-driven sanctions were implemented by the U.S., United Nations, and the European Union because of allegations against Iran's nuclear program. Although economic sanctions are supposed to address the nuclear program policies of Iran, they mainly impact ordinary citizens' lives by exerting economic pressure on the society as a whole.

Even though the Iranian government does not want to admit its vulnerability to foreign forces and does not publish any document revealing the effects of sanctions, documents and reports published from international organizations, such as the U.S. Congressional Research Service and the U.S. Department of Treasury, show how the sanctions have been affecting the Iranian state. However, these reports rarely point to the impacts of the sanctions on human rights or on vulnerable populations, such as women, children, and students. Despite the dearth of factual and statistical information regarding the impacts of the sanctions (Amuzegar, 1997), in this paper, I will focus on the consequences of the economic sanctions on the higher education system. I will begin my analysis using existing research and literature and will then propose a model for analyzing policies related to the economic sanctions and higher education in Iran. In the next section, I will review the related literature about what I consider to be the social problem, i.e., detrimental effects of the economic sanctions on vulnerable populations of societies and on education systems, and will explore previous solutions to policy problems. I will divide the related literature into two subsections. First, looking at the history of different 
sanctions, I will explore whether or not economic sanctions have been successful strategies and policies to reach their intended goals. Then, I will review the studies that focus on the deleterious/corrosive effects of sanctions on human rights. Furthermore, I will elaborate on my choice of policy analysis model as a theoretical framework and accordingly will discuss the policy problem. Since this paper will propose a policy analysis model for economic sanctions, I will establish my evaluation criteria in the analysis. Finally, I will argue about the economic sanctions as global policies against Iran and will suggest global citizenship education as a means to stop enacting such unjust policies against a nation.

\section{Review of the Related Literature}

Economic sanctions have become an increasingly common feature of international politics. According to Galtung (1967), sanctions are policies and actions initiated by one or more international actors against one or more others. Peksen (2009) states that economic coercion is imposed by sender countries with "a variety of foreign policy goals, ranging from preventing bloodshed between ethnic groups to punishing countries harboring terrorists, restoring democratic regimes, or ending the use of repression by the government" (p. 59). However, the effectiveness of economic sanctions as a means of foreign policy has been a question among sanction scholars (Bolks \& Al-Sowayel, 2000). Moreover, economic sanctions, beyond their intended policy goal, impose major socio-economic and political damage in target countries

(Peksen, 2009). To put it simply, economic sanctions can be a damaging foreign policy tool, due to the destabilizing effects they produce in target countries. Studies (Cortright \& Lopez, 1995; Weiss, 1999; Gibbons, 1999) show that economic sanctions cause disproportionate pressure on ordinary citizens. Recent research also sheds light on the effects of sanctions on basic human rights (Peksen, 2009; Weiss, 1999) and especially their effect on local women (Drury \& Peksen, 2012).

\section{Sanctions: Success or Failure}

Studies of economic sanctions traditionally have tended to focus on the effectiveness of sanctions achieving their purpose. However, the outcome of these studies is often debated. A growing body of literature claims that sanctions can be an appropriate and successful substitute or complement for military forces. For example, Rogers (1996) argues: 
Economic sanctions are more effective than most analysts suggest. Their efficacy is underrated in part because unlike other foreign policy instruments sanctions have no natural advocate or constituency [...] Economic sanctions have no equivalent champion. As a result, their successes are widely unreported, while their failures are exaggerated by those with an interest in either avoiding their use, or in using other instruments. (p. 72)

Shambaugh (1999) examines the post-1945 history of U.S. sanctions against foreign firms and argues that the record of extra-territorial sanctions is much more complex than previously thought. He shows that the effectiveness of these sanctions has been greater than expected (50\% exactly). Aligned with this view, Katzman (2010) provides statistical information about the effects of sanctions on Iranian society, explaining how these sanctions were successful in their goal by first destabilizing the economy of the country. Marinov (2005) shows that economic sanctions do work in at least one respect: "they destabilize the leaders they target" (p. 564). He argues that the leader of a government who falls under economic pressure is more likely to lose office than a leader who does not:

The practice of imposing costs through economic pressure is often justified as a means for changing the behavior of a foreign government. Leaders are more likely to compromise if pressure threatens their survival in office. My basic conclusion is that sanctions are more likely to coerce than previously thought. (p. 564)

On the other hand a number of studies claim that sanctions most often fail to affect policy change in the target. Scholars, such as Pape (1997) and Galtung (1967), allege that economic sanctions are generally ineffective in persuading target countries to fulfill the sender's demands. Focusing on the case of Rhodesia, Galtung (1967) asserts that "in a sanction process a receiving nation is greatly aided by general tendency to underestimate it" (p. 406). Analyzing the target society as an organism with certain self-maintaining potential, he argues that the likely effectiveness of economic sanction is negative. He believes:

When hit and hurt it reacts- like most organisms- in such a way as to try to undo the damage and to restore the status quo ante. In so doing, the target society may even be partly strengthened because of the hidden forces that are activated. (p. 409)

Gultung (1967) explains that most sanctions are unsuccessful because they are compared to interpersonal relations: when one person punishes another person and expects changes in 
his/behavior, it often does not change their behavior. He goes further and states that there is a "lack of isomorphism between interpersonal and international relation: what works at the individual level does not necessarily work at the level of interaction between nations, which is characterized by collective actions" (p. 409).

Challenging the validity of Hufbauer, Schott and Elliott, (1990), Pape (1997) examines the 40 claimed successes and found that only 5 stand up to scrutiny. He argues that 18 were actually settled by either direct or indirect use of force; in 8 cases there was no evidence that the target state made the demanded concessions; 6 did not qualify as instances of economic sanctions; and 3 were indeterminate. Accordingly, he claims that sanctions have succeeded in only 5 of 115 attempts. He further argues that the study of economic sanctions from 1914 to 1990 confirms that there is little valid social scientific support for claims that economic sanctions can achieve major foreign policy goals.

In the case of Iran, a recent Gallup Poll taken in December 2012 regarding the impact of international sanctions on Iran shows that although sanctions on Iran have significantly increased overall hardships and negative living conditions of the Iranian people, they have failed to significantly undermine popular support for Iran's nuclear ambitions (GALLUP World, 2013).

\section{Sanctions and Human Rights}

Regardless of the success rate of sanctions, they are used frequently as a foreign policy tool. Recognizing this, new research has moved beyond the issue of sanction effectiveness to deal with the consequences of economic sanctions on the target nation. Focusing on the UN sanctions against Iraq, Lopez and Cortright (1997) argue that further deterioration of human rights conditions was an unintended consequence of economic sanctions caused by disproportionate economic hardship on Iraqi civilians. Regarding unintended consequences of the economic sanctions, Albright (2000) states that:

When the $[\mathrm{UN}]$ or the $[\mathrm{U} . \mathrm{S}$.] imposes sanctions against a regime . . it does not intend to create unnecessary hardships for innocent people, especially children and infants. Good intentions, however, do not automatically translate into good results. (p. 155)

A New York Times article called the U.S. sanctions on Burma a "feel-good substitute" for policy and predicted that they would cause "babies to die, young women to succumb to AIDS 
and families to go hungry" (Kristof, 2003, ๆ 6). In this regard, Rao (2000) points to a UNICEF survey and argues that the health and well-being of children is being severely affected by UN sanctions on Iraq. Questioning the silence of Western human rights activists, he adds that these overlooked deaths in Iraq are a scar on the face of humanity. Garfield (1999) argues that economic sanctions affect the quality of health care and can have huge negative implications on child health. He asserts that insufficient vaccines in sanctioned countries can lead to outbreaks of diphtheria, tetanus, and pertussis. Moreover, shortages of oil, gas, and electricity mean frequent power cuts and fuel shortages which affect emergency medical services, heating hospitals, and patient transportation to hospitals. These poor conditions in hospitals lead to increase in maternal mortality and complications at birth. Hospitals also have fewer supplies and perform fewer tests (Garfield 1999). Drury and Peksen (2012) argue that economic sanctions have a negative impact on women's status in the target countries. They show that the gender inequality in gaining access to economic and social status, as well as traditional patriarchic norms, make women susceptible to economic and political crises. They believe that economic sanctions create crises by preventing the regular functioning of the target economy and creating conditions for greater violations of women's rights.

None of these studies, however, provides a cross-national, empirical examination of the extent to which economic sanctions affect the education systems of target countries. Therefore, we are still far from understanding the effects that economic sanctions have on higher education.

\section{Theoretical Framework \& Policy Research Model}

According to Pal (2010), problem structuring and definition involves diverse techniques aimed at probing an issue that had been signaled in some ways as a possible policy problem. He believes that "the process of problem definition is one of shaping a persuasive argument about the nature of the problem and the solution" (p. 118). In this article I will use an adapted version of Rochefort and Cobb's (1994) model of policy arguments and problem definition, introduced by Pal (2010). Pal defines policy argument as "an organized set of claims about a policy problem and recommended solutions that include such characteristics as causality, severity, novelty, crisis, instruments, and solutions" (p. 139).

Elaborating on each aspects of policy argument, Pal argues that "causality" deals with kinds of causal factors that underlie the problem. He states that "severity" focuses on how bad 
the problem is, and how bad it is likely to get. For him this distinguishes between "the acknowledged existences of a problem" and is usually "measured against some backdrop or context, such as trend lines or what is considered normal or deviant" (p. 118). He believes that an argument should address the scope and impact of the problem, i.e., "incident". For him "incidents" deal with questions such as "who is affected generally?," "what subgroups are affected and how?," "what patterns of incidence are most important?" (p. 118). Pal believes that in an argument, policy analysts need to argue the "novelty" of the problem and the "proximity" of it to see how sever the issue is. A policy argument, as Pal (2010) says, should address the problem "population" and the people who are potential targets of policy interventions. He believes that we should elaborate on "how important is the process of solving the problem in comparison to the solution itself?" (p. 119). Finally, a policy argument includes a "solution". He believes that solutions sometimes lead the problem and help shape it.

I will frame my policy argument as narratives. According to Elliott (2005), “a narrative organis[es] a sequence of events into a whole so that the significance of each event can be understood through its relation to that whole' and thereby becomes a tool for conveying 'the meaning of events" (as cited in Lewis, 2008, p. 561). Means (2002) argues that political narratives "do work on the emotions by forcing us to begin to encounter that with which we cannot identify (even if it is familiar); however, this is a feature of its capacity as a form of reason-giving, not an autonomous function" (p. 225). According to Nussbaum (1995), narrative arguments introduce us "to that which is in a way common and close at hand - but which is often, in its significant strangeness, the object of profound ignorance and emotional refusal" (p. $10)$.

Although this paper is framed based on my understanding of the problem and the analysis of the existing documents, I contend that narrative policy analysis will help better understand and analyze the effects of the economic sanctions on higher education in Iran. Narrative policy analysis builds on literary theories that emphasize the ways in which power is embedded in language (Roe, 1994). Gerstl-Pepin (2006) believes that to understand policy stories, it is important to understand power as the ability of a group, individual, or structure to use control or authority. Pointing to Collins (2000), Gerstle-Pepin (2006) argues that "power relations are unequal and operate on an array of levels" (p. 152). She adds that these power relations embrace overt and covert exertions of control and domination, including individual experiences of 
prejudice and bias and structural forms of power (such as policies, organizational structures, or legislation). Policies are a form of power that operate through a "constellation of organized practices in employment, government, education, law, business, and housing that work to maintain an unequal and unjust distribution of resources" (Collins, 2000, as cited in GerstlePepin, 2006, p. 145). Gerstle-Pepin (2006) claims that while policy issues are highly complex and uncertain, narrative policy analysis provides a way of examining how policy stories shape policymaking. Roe (1994) argues that policy narratives provide a way of exploring how stories are used to shape policy issues. Using narrative policy analysis, in the case of the economic sanctions against Iran and their consequences for higher education, further, I will try to build a more comprehensive picture of policy issues.

\section{Policy Problem}

\section{Economic Sanctions and Effects on Iranian Society}

As a substitute to military force, U.S. sanctions have been the main feature of U.S. - Iran policy since Iran's 1979 Islamic revolution (Katzman, 2013). This tension with Iran has been replicated by the United Nations and the European Union since 2006 as a response to Iran's nuclear program. In a report on Iran's sanctions, delivered to the U.S.'s Congressional Research Service, Katzman (2013) argues:

The objectives of U.S. sanctions have evolved over time. In the mid-1980s, U.S. sanctions were intended to try to compel Iran to cease supporting acts of terrorism and to limit Iran's strategic power in the Middle East more generally. Since the mid-1990s, U.S. sanctions have focused increasingly on persuading or compelling Iran to limit the scope of its nuclear program to purposes that can only be civilian. As Iran's nuclear program has been increasingly identified as a potential threat to stability in the Middle East and global energy supplies, the international community has joined U.S. sanctions to try to force Iran to verifiably demonstrate that the program is for purely peaceful purposes. (p. 1)

As stated before, while the purpose of these imposed sanctions is to weaken the power of the Iranian state, "a great number of states and humanitarian organizations have expressed concerns at the possible adverse impact of sanctions on the most vulnerable segments of the population” (UN Security Council Sanctions Committees, 2006, I 4). Part of these concerns is related to the negative impacts that sanctions can have on the economy of the target countries, 
which can be seen as an important element of a nation-state's well-being (Gibbons and Garfield, 1999). According to a Gallup survey conducted in Iran in December 2012- January 2013, a majority of Iranians (56\%) say sanctions imposed by the United Nations, the U.S., and Western Europe have hurt Iranians' livelihoods a great deal, and an additional 29\% say sanctions have hurt them somewhat. Moreover, $48 \%$ say sanctions have affected their own personal livelihoods a great deal and another 35\% say somewhat (GALLUP World, 2013).

Despite the fact that Iran, as a developing country, has tried to focus on self-development strategies following the Islamic revolution, it has been stifled by the economic restrictions imposed by international policies. The sanctions restrict missile, nuclear, and military exports to Iran, investments in oil, gas and petrochemicals, exports of refined petroleum products, business dealings with the Iranian Republican Guard Corps, as well as banking and insurance transactions (including any financial activity with the Central Bank of Iran) and shipping (Fayazmanesh, 2003). The current sanctions put Iran, whose economy is dependent on its oil and gas industries, in a position that seeks ways to defy the sanctions with the help of some of its allied countries, including some Latin American countries and Afghanistan. Iran attempts to attract energy investment interest from "firms primarily in Asia, which appear eager to fill the void left by major European and American firms and to line up steady supplies of Iranian oil and gas" (Katzman, 2009, p. 5). Despite this, Iran is facing a remarkable toll on its economy. In October 2012, Iranian president, Mahmoud Ahmadinejad, attributed a 40 percent fall in value of the Iranian currency, The Rial, to the American-led economic sanctions on the country (Erdbrink. 2012). The currency collapse consequently has caused a hyperinflation on Iran's economic system, adversely affecting many sectors of the society. Steve H. Hanke, an economics professor at Johns Hopkins University, sees currency collapse as a side effect of economic sanctions and argues "when a currency collapses, you can be certain that other economic metrics are moving in a negative direction too" (as cited in Gladstone, 2012, ๆ 7).

\section{The Effects of Sanctions on University Life.}

One of the sectors being affected by the economic situation of the country is higher education. Iran has a large network of public and private universities. Among 2390 universities, about 5\% are public universities under the direct supervision of Iran's Ministry of Science, Research, and Technology (MSRT), about 66\% are semi-public universities (including Ministry 
of Education Universities, Payame-Noor Universities, Jame-Elmi-Karbordi Universities, and governmental universities) under the supervision of different organizations, and $28 \%$ are private and non-governmental universities (including Azad and Gheyre-Entefaee Universities) (University Portal, 2011). While policies relating to the public universities is directed by the MSRT, other universities, whose policy making is not under the supervision of MSRT, try to align with national policies. This is while the budget devoted to the public sector is coming from governmental allocations and the budget of the private section is provided by private investment and high tuition fees. Hence, universities are integrally dependent on the country's economic situation.

Economy, the Drop of the Value of Currency, and Budget Cuts.

In the public sector, in 2012-2013, Iran slashed 3\% of higher education spending (University Portal, 2013). This budget cut, which is expected to be continued in coming years due to the critical economic situation of the country, can harm the universities and their qualities in different ways. Although policy makers and administrators are not willing to talk about the negative effects of budget cuts, Iranian students experience the consequences of such cuts with crowded classrooms and low quality facilities. Moreover, since the budget allotted to the universities is counted by the Iranian currency, Rial, the currency collapse has reduced universities' ability to pay for any technology and service whose medium of exchange is dollar. For example, Iranian universities cannot afford to pay the subscription fees of scientific databases, such as Scopus and Science Direct (Khandan, 2013). Hence, the lack of access to scientific journals has challenged academia and made staff and students alike struggle for their basic academic needs.

\section{Restrictions on International Bank Transactions.}

According to some of the non-UN mandated and UN sanctions, any bank transaction to Iran (except some cases) as well as importing and exporting a wide range of goods and technology to/from Iran are prohibited (Government of Canada, 2013). While Iranian universities are claimed to have improper equipment and facilities, including libraries and laboratories (Torbat, 2002; Mashayekhi, 2001), the recent consequences of the sanctions has exacerbated the situation by restricting the import of the most updated technological tools and equipment.

\section{High Tuition Fees and Low Access to Universities.}


Iranian private universities are facing additional problems compared to the public universities. Since these universities are dependent on private investments and students' enrollments, the current economic context of the country has exerted economic pressure on these universities. In September 2013, the Iranian Central Bank estimated that the inflation rate is about 37\% (Trading Economics, 2013), while many economists otherwise believe the actual rate is between $50 \%$ and $70 \%$ (Katzman, 2013). Despite the fact that hyperinflation has affected the prices of goods and services, people's earnings have not changed. This disparity between prices of goods/services and earnings needs students to struggle to pay high post-secondary tuition fees. This implies that many youths who want to study in post-secondary institutions may consider public universities as their only option, since they are unable to pay for private or semi-private universities.

\section{Marginalization within the International Academic Community.}

Lack of financial aid has impeded Iranian students and academics from participating in the international academic arena, especially within scientific conferences. This issue, along with difficulties in getting VISAs from the countries in which conferences are held, has pushed Iranian academics to the periphery and has isolated them.

\section{Iranian Students Abroad and Financial Problems.}

Besides the problems that academics experience within Iran, students who study abroad are also affected by these economic sanctions. After the currency collapse, many students who had not been funded neither by the Iranian government nor by the target universities and had been counting on their familial financial support, had to return to Iran since they were unable to pay their tuition fees in their country of study (Torbati, 2012). Some others, who decided to stay in their program abroad, are struggling financially.

Since my aim is to appraise the sanctions and to show how they affect the lives of ordinary citizens and vulnerable populations in Iran, I will examine Iran's position in relation to other countries with particular focus on the United States as a driving force of economic sanctions. Narrating the history of Iran, I will try to show how Iran's geographic position in the Middle East, combined with its leaders' views on America has shaped international policies toward Iran. 


\section{Human Rights as a Basis for Policy Argument}

Given that in this analysis I am focusing on the issue of education, as a human right which has been violated using the economic sanctions, I see a need to elaborate on the criteria based on which I judge human rights. Lukes (2003) believes that the principle of defending human rights is "accepted virtually everywhere. It is also violated virtually everywhere, though much more in some places than in others." (p. 154). Based on such a view, I will rely on the United Nation's Universal Declaration of Human Rights (UDHR). Nowadays this declaration is known as a universal standard of achievement for all societies in terms of rights. For the UN, Human rights are commonly understood as being "those rights which are inherent to the human being” (UN, 2011, ๆ 1). According to the UN (2011) the concept of human rights acknowledges that "every single human being is entitled to enjoy his or her human rights without distinction as to race, colour, sex, language, religion, political or other opinion, national or social origin, property, birth or other status.” (\1). The following are some of the most important characteristics of human rights for the UN (2011):

- Human rights are founded on respect for the dignity and worth of each person;

- Human rights are universal, meaning that they are applied equally and without discrimination to all people;

- Human rights are inalienable, in that no one can have his or her human rights taken away; they can be limited in specific situations (for example, the right to liberty can be restricted if a person is found guilty of a crime by a court of law);

- Human rights are indivisible, interrelated and interdependent, for the reason that it is insufficient to respect some human rights and not others. In practice, the violation of one right will often affect respect for several other rights.

- All human rights should therefore be seen as having equal importance and of being equally essential to respect for the dignity and worth of every person. ( $\mathbb{4} 4)$

Given these definitions and scopes, Article 26 of the declaration points to the education as a human right:

Everyone has the right to education. Education shall be free, at least in the elementary and fundamental stages. Elementary education shall be compulsory. Technical and professional education shall be made generally available and higher education shall be equally accessible to all on the basis of merit. (UDHR) 
As I mentioned, there are many justifications for imposing economic sanctions against Iran. Since one of the main parties in enacting sanctions against Iran is the United Nations, I see a need to criticize this organization's actions and policies towards Iran. Although UN is globally known for its actions and initiatives towards human rights, it has been violating human rights in Iran by sanctioning the country. Referring to normative ethics, I see the UN's policies and reactions against Iran aligned with Utilitarianism, wherein people "display a strong sense of collective purpose: their single and exclusive goal, overriding all other, is to maximize the overall utility of all of them" (Lukes, 2003, p. 155). However, there is a problem in such a view, as it legitimizes innocent people being sacrificed, if their sacrifice will make the majority happier (Lukes, 2003). The former Democratic Secretary of State Madeleine Albright, when asked in 1996 about reports that 500,000 Iraqi children had died as a result of U.S.-imposed sanctions on that country, replied: "I think this is a very hard choice, but the price - we think the price is worth it" (Greenwald, 2012, ๆ 7).

While the sanctions against Iran are justified in the name of avoiding the threats of terrorism and weapons of mass destruction for a greater good, the world is witnessing a scandalous ignorance of humanity in such policies. Dostoyevsky (2001) perfectly addresses such an issue by asking a critical question:

Imagine that you are creating a fabric of human destiny with the object of making men happy in the end, giving them peace and rest at last. Imagine that you are doing this but that it is essential and inevitable to torture to death only one tiny creature? that child beating its breast with its fist, for instance? in order to found that edifice on its unavenged tears. Would you consent to be the architect on those conditions? Tell me. Tell me the truth? (p. 246)

Although I am in favor of seeing education as a right and respecting human rights in the current world order, in which power plays an important role in ruling individuals and societies, I wish I could look at the world with a Proletarian lens. As Lukes (2003) explains, Proletaria, is a dream land where everyone respects each other and there are not any problematic binaries, such as class, race, and gender, so there is not any need to bring up the issues such as human rights. Although in the current world order such a land is an ideal rather than a state of existence and we may not achieve it, we can make sure that we pursue it as a model.

\section{Policy Argument: A Historical Overview}




\section{Pushing Forces of the Islamic Revolution}

During Mohammad Reza Shah's ascendancy to power (1941-1979), United States of America was the best ally of Iran. Indeed, Iran's extensive border with America's Cold War rival, the Soviet Union, and its position as the most powerful country in the oil-rich Persian Gulf, made Iran a pillar of U.S. foreign policy in the Middle East (Teicher \& Teicher, 1993). While Iran's oil and gas resources were of interest of the U.S., Mohammad Mosaddeq's (the Prime Minister of Iran in 1951-195) social and political reforms restricted its control over Iran's resources. Mosaddeq, who had identified himself with two main issues: "a desire to transfer political power from the royal court to the parliament (known as the Majlis)", and an aspiration "to increase Iran's control over its oil industry, which was controlled by the British-owned Anglo-Iranian Oil Company" (Gasiorowski, 1987, p. 262), dedicated himself to reach his aims by his ascendance to power. Nationalization of the Iranian oil industry, which was the pillar of Britain's economy since 1913, was the most significant reform in Mosaddeq's government. As Gasiorowski (1987) narrates, the nationalization policies very soon brought Mosaddeq into clash with the British government, which owned 50\% of the AIOC's stock and was not ready to admit the nationalization. He adds that, in the following months after the nationalization initiatives, the British government adopted different strategies to reestablish its control over Iran's oil by forcing Mosaddeq into a favorable settlement using different embargos and sanctions and finally removing him from the Iranian government. Moreover, Shah, who had found himself in a weak position after the embargos, left Iran with the hope of finding a supporter to help him to pull Iran out from quagmire of economic hardship resulted from the sanctions. At the same time, the United States supported the British embargos and Central Intelligence Agency (CIA) station in Tehran carried out "covert activities" against Mosaddeq and the National Front since the summer of 1952 (Gasiorowski, 1987, p. 243). Their strategies from legal maneuvers to economic sanction and carrying out military maneuvers in the region, were followed by a coup d'état, with the help of the CIA, aiming at removing Mosaddeq from the power. Nirumand (1969) states that, the main motive behind the coup was the desire of U.S. policymakers to help U.S. oil companies gain a share in Iranian oil production. This is while Gasiorowski (1987) argues that U.S. policymakers were provoked chiefly by fears of a communist takeover in Iran, and that the involvement of U.S. companies was sought mainly to prevent this from occurring rather than commercial interest. He adds that the decision to overthrow Mosaddeq was as one more step 
ahead in the international effort of the Eisenhower's ( $34^{\text {th }}$ President of the States) administration to obstruct Soviet expansionism.

Following the coup, in the situation that Iran's economy was severely destabilized and damaged by embargos and sanctions, U.S. helped to build up the Shah's regime with substantial financial aids (Gasiorowski \& Byrne, 2004). These supports made the U.S. as the best ally of Iran and this was a turning point in Iran's national and international policies. While Americanization had become as the main national policy of Iran, three of Iran's top universities were introduced as the main sites for establishing American culture. Shiraz (Pahlavi) University, Sharif (Aryamehr) University of Technology, and Isfahan University of Technology were directly modeled on American institutions, such as the University of Chicago, MIT, and the University of Pennsylvania (University of Pensylvania, 2006; Leslie \& Kargon, 2006).

CIA's attempts to remove Mosaddeq, whose anti-imperialist/nationalist policies had made him an idol among Iranian citizens, along with Americanization policies of Shah and social pressures that CIA-led Iranian secret police force (SAVAK) had exerted on the society after the Shah's return, led to anti-U.S. protests during the 1970s.

\section{Islamic Revolution Countering Western Cultural Hegemony}

The 1979 Islamic Revolution in Iran ended a mutually beneficial relation between the U.S. and the Shah, wherein the latter helped to serve the economic and political interests of the former in the region and the former helped to protect the power of the Shah (Fayazmanesh, 2002). The revolution changed the direction of Iran's foreign policy significantly. Iran started to negotiate with other countries about its Islamic and anti-American values and policies. Iran-U.S. conflicts increased when thousands of young Iranians, mostly university students, swarmed the U.S. embassy in Iran and hold 52 Americans as hostages for 444 days. This crisis led to the U.S.'s legal actions against Iran, namely economic sanctions according to which Iran-U.S. economic relations got limited. Moreover, Iran, which was planning to improve its infrastructures, in the midst of the hostage crisis in 1980 and in the situation that its armed forces were paralyzed by U.S. sanctions, got involved in an imposed war with Iraq for eight years. Saddam Husayn, who was provoked and supported by the U.S., was "determined to replace the Shah as the region's hegemon and to squelch the radical Islamists' efforts to export their 
revolution across the Gulf and into Iraq" (Milani, 2004, p. 2). Brzezinski and Scowcroft (1997) explain U.S.'s policies towards Iran in that era as the following:

During the 1980s, the United States strove to maintain a de facto balance of power between Iraq and Iran so that neither would be able to achieve a regional hegemony that might threaten American interests. The United States provided some help to Iraq during the Iran-Iraq War of 1980-88 [by providing chemical weapons to attack Iran], moved in other ways to counter the spread of Iranian-backed Islamic militancy, and providedwith Israeli encouragement-some help to Iran, chiefly in the context of seeking the release of American hostages. (pp. 4-5)

\section{Solutions to the Problem}

Sanctions against Iran have a long history. Regardless of the purpose of the sanctions against Iran, it is evident that in this battle for power and wealth, ordinary citizens and especially vulnerable population of the society, such as students, get hurt. In such a situation, it is apparent that Iran, as a state which has the claim of self-reliance and power, seeks ways to get out of such a situation and to alleviate the economic hardship. Although there are diversity of views in terms of how to deal with this situation, all parties agree that Iran should not give up easily and should keep up resisting against the Western hegemony. This is while ordinary people are the ones who pay the expense of such a resistance. This is while, according to GALLUP (2013), the majority

of Iranians are so far seemingly willing to pay the high price of sanctions. Sixty-three percent say that Iran should continue to develop its nuclear program, even given the scale of sanctions imposed on their country because of it. In December 2012, one in two Iranians supported their country developing its own nuclear power capabilities for nonmilitary uses. This has made the situation even more complex, as on one hand, there is the revolutionary mission, i.e., resisting against Western imperialism for which people paid the price in the revolution time, and on the other hand, there are ordinary citizens who are struggling for their basic life expenses, despite their will to continue the peaceful nuclear program. Apparently, there are controversies over the solution to the problem. Being accused of mismanagement, neo-fundamentalist party in Iran sees the current stance against the international pressure as the best solution to the problem. This is justified by the point that firm resistance against the U.S. will make it step back from its demands, as it is well aware of the Iran's power. However, for other parties such as reformists, 
the only solution to get the people out of such a context is to negotiate with the U.S. and to accept its legal demands in terms of the nuclear activities and program.

\section{Raising Awareness}

Regardless of the direction of any of these solutions, it is evident that economic sanctions are threatening human rights in Iran. This is while United Nation, which is supposed to address human right violations in societies, is acting contrary to its own visions by ignoring the very effects of the sanctions against Iran. To address such an issue, a good solution can be publishing data, statistics, and facts that show how these sanctions have been affecting the life of vulnerable populations in Iran. For example, by releasing the information related to the impacts of the sanctions on student life, Iran can stand against the myth that the high rate of brain drain in Iran is mainly as the result of the social and political pressures in the society due to the government's mismanagement. Such information can also help to awaken many human right activists in the world to stand for Iranian citizens whose very basic right, i.e., education, is in danger by economic sanctions. Lobbying for human rights in Iran may stop such sanctions and may lead the West world, specifically the U.S., to choose a more diplomatic solution to deal with Iran based on which ordinary citizens do not get hurt.

\section{The Role of Global Citizenship Education}

Many of the global actions and policies are justified by referring to public the opinion about the related issue. According to PEW Research Center (2013), majorities in most of 39 countries surveyed have an unfavorable opinion of Iran. For example, in North America, about seven-in-ten in the U.S. (69\%) and Canada (70\%) have an unfavorable opinion of Iran. According to this report, publics differ when it comes to the use of economic sanctions to prevent Iran from acquiring nuclear arms. Approximately three-quarters or more of those who oppose Iran's nuclear program in the U.S. (78\%), Germany (77\%), Britain (75\%) and France (73\%) approve of tougher economic sanctions to deter Iran from developing nuclear weapons. This is while there is no evidence to prove that Iran's nuclear program is hostile and Iran's attempt has been to prove that its program is following a peaceful mission and will not be used for violent purposes.

This contradiction between the global public opinion against Iran and the reality of 
Iranian citizens' lives can have some implications for policy makers and educators around the world. Since in any democratic country, citizens are invited "to be engaged in issues and actions beyond their local context" (Shultz, 2007, p. 257) and to consider themselves as citizens of the world, there is a need to consider the role of education in training citizens for whom equality, global justice, and global peace are among their leading values. According to the UK Oxfam Education (2006), a "global citizen" is someone who is "aware of the wider world and has a sense of their own role as a world citizen," "respects and values diversity" and thus, is interested in making the world "a more equitable and sustainable place" (p. 3). Following such a view, global citizenship education can have some important implications in favor of the countries which are affected by economic sanctions:

- raising awareness about the history of the targeted countries and untold stories behind the economic sanctions

- revealing the role of "power" and "economy" in shaping the current world order and the global agenda

- raising awareness about the violation of human rights (such as education) in the targeted countries as the result of the economic sanctions

- $\quad$ showing the role of media in shaping public opinion and trying to make counter narratives based on factual basis and stories

- inviting actions towards global justice and global peace

\section{Conclusion}

Grounded in the related literature I showed how economic sanctions, as foreign policies, can have detrimental effects on the human rights in the targeted societies. According to the United Nations, education is a basic human right and higher education should be accessible to everyone (UDHR, 2011). Economic sanctions influence the economy and consequently affect access to and quality of higher education in the targeted country. Although the effects of sanctions extend beyond the weakening of the education systems, I see a need to focus on the education aspect, since it plays a very important role in any society's development and in any individual's mobility. Narrating the history of Iran, I attempted to demonstrate how international interference has been affecting the country's development and growth. Moreover, the effects of such interferences have not only been limited to the state's well-being, but have gone further to 
the Iranian nation's welfare. Although in validating such a statement, there is a call for more empirical research to hear more authentic and real stories of citizens being affected by these sanctions, policy makers need to consider all of the consequences of their designed policies and need to consider ethics based on which ordinary citizens and vulnerable populations feel safe and secure; a global ethics which cares about humanity and values the very rights of each human being. To this end, global citizenship education can play a very important role since it has "its roots in justice" (Shultz \& Jorgenson, 2008, p. 3) and, thus, can promote global awareness and peace. 


\section{References}

Albright, M. K. (2000). Economic sanctions and public health: a view from the department of State. Annals of Internal Medicine, 132(2), 155-157.

Amuzegar, J. (1997). Adjusting to Sanctions. Foreign Affairs, 73(3), 31-41.

Bocock, R. (1986). Hegemony. Chichester: Ellis Horwood.

Bolks, S. M., \& Al-Sowayel, D. (2000). How long do economic sanctions last? Examining the sanctioning process through duration. Political Research Quarterly, 53(2), 241-265.

Brzezinski, Z., \& B. Scowcroft., (1997). Differentiated containment: U.S. policy toward Iran and Iraq. Washington, DC: Council on Foreign Relations.

Brzezinski, Z., Scowcroft, B., \& Murphy, R. (1997). Differentiated containment. Foreign Affairs, $76,20$.

Bullock, A. (1999). The new Fontana dictionary of modern thought. HarperCollins.

Cortright, D., \& Lopez, G. A. (1995). Economic sanctions: Panacea or peacebuilding in a postcold war world? Boulder: Westview Press.

Dostoyevsky, F. (2001). Ivan speaks of human cruelty. In A, Rorty, (Ed.). The many faces of evil: Historical perspectives (pp. 241-247). London: Routledge.

Drury, A. C., \& Peksen, D. (2012). Women and Economic Statecraft: The Negative Impact International Economic Sanctions Visit on Women. European Journal of International Relations.

Elliott, J. (2005). Using narrative in social research: Qualitative and quantitative approaches. London: Sage Publications Limited.

Erdbrink, T. (2012). Iran's President Ties Recent Drop in Currency to U.S.-Led Sanctions. New York Times. http://www.nytimes.com/2012/10/03/world/middleeast/iran-presidentmahmoud-ahmadinejad-ties-currency-drop-to-sanctions.html?_r=0

Fayazmanesh, S. (2003). The politics of the US economic sanctions against Iran. Review of radical political economics, 35(3), 221-240.

Galtung, J. (1967). On the effects of international economic sanctions, with examples from the case of Rhodesia. World Politics, 19(3), 378-416.

GALLUP World, (2013). Iranians Feel Bite of Sanctions, Blame U.S., Not Own Leaders. Retrieved from: http://www.gallup.com/poll/160358/iranians-feel-bite-sanctions-blamenot-own-leaders.aspx 
Garfield, R. S. (1999). Morbidity and mortality among Iraqi children from 1990 through 1998: Assessing the impact of the Gulf War and economic sanctions. London: Campaign against sanctions on Iraq.

Gasiorowski, M. J. (1987). The 1953 coup d'etat in Iran. International Journal of Middle East Studies, 19(3), 261-286.

Gasiorowski, M. J., \& Byrne, M. (2004). Mohammad Mosaddeq and the 1953 coup in Iran. Syracuse: Syracuse University Press.

Gerstl-Pepin, C. I. (2006). The paradox of poverty narratives educators struggling with children left behind. Educational Policy, 20(1), 143-162.

Gibbons, E. D. (1999). Sanctions in Haiti: Human rights and democracy under assault (Vol. 177). Westport: Greenwood Publishing Group.

Gibbons, E., \& Garfield, R. (1999). The impact of economic sanctions on health and human rights in Haiti, 1991-1994. American Journal of Public Health, 89 (10), 1499-1504.

Gladstone, R. (2012). A new sign of distress as Iran's currency falls. New York Times. Retrieved from: http://www.nytimes.com/2012/10/02/world/middleeast/irans-rial-plummetsagainst-the-dollar.html

Government of Canada. (2013). Foreign affairs, trade, and development Canada: Iran. Retrieved from: http://www.international.gc.ca/sanctions/iran.aspx

Greenwald, G. (2012). Iran sanctions now causing food insecurity, mass suffering. The Guardian. Retrieved from: http://www.guardian.co.uk/commentisfree/2012/oct/07/iransantions-suffering

Hufbauer, G. C., Schott, J. J., \& Elliott, K. A. (1990). Economic sanctions reconsidered: Supplemental case histories. Washington: Institute for International Economics.

International Monetary Fund (IMF), (1999). How extensive is the brain drain? Finance and Development. A quarterly magazine of IMF, 36 (2).

Katzman, K. (2009). Iran Sanctions Act (ISA). CRS Report for Congress, Congressional Research Center.

Katzman, K. (2010). Iran Sanctions: Congressional Research Service Report Prepared for Members and Committees of Congress. Darby: Diane Publishing Co.

Katzman, K. (2013). Iran Sanctions: CRS Report for Congress. U.S's Congressional Research Service. 
Khandan, E. (2013). Lack of access to scientific databases: a consequence of economic sanctions or lack of budget. $B B C$ News. Retrieved from: http://www.bbc.co.uk/persian/science/2013/01/130125_ka_science_iran.shtml

Kristof, N. D. (2003). Our man in havana. The New York Times. Retrieved from: http://www.nytimes.com/2003/11/08/opinion/our-man-in-havana.html

Leslie, S. W., \& Kargon, R. (2006). Exporting MIT. Osiris, 21(1), 110-130.

Lopez, G. A., \& Cortright, D. (1997). Economic sanctions and human rights: Part of the problem or part of the solution? The International Journal of Human Rights, 1(2), 1-25.

Lukes, S. (2003). Five fables about human rights. In S. Lukes, (Ed.), Liberals and cannibals: The implications of diversity (pp. 154-170). London: Verso Press.

March, J. (1972). Model bias in social action. Review of Educational Research, 42, 413-429.

Marinov, N. (2005). Do economic sanctions destabilize country leaders? American Journal of Political Science, 49(3), 564-576.

Mashayekhi, M. (2001). The revival of the student movement in post-revolutionary Iran. International Journal of Politics, Culture and Society, 15(2), 283- 313.

Means, A. K. (2002). Narrative argumentation: Arguing with natives. Constellations, 9(2), 221245.

Milani, M. M. (2004). Iran's transformation from revolutionary to status quo power in the Persian Gulf. Iran After, 25.

Nirumand, B. (1969). Iran; the new imperialism in action. New York: Monthly Review Press.

Nussbaum, M. C. (1995). Poetic justice: The literary imagination and public life. Boston: Beacon Press.

Pal, L. A. (2010). Beyond policy analysis: Public issue management in turbulent times. Scarborough, Ontario: ITP Nelson.

Pape, R. A. (1997). Why economic sanctions do not work. International Security, 22(2), 90-136.

Peksen, D. (2009). Better or worse? The effect of economic sanctions on human rights. Journal of Peace Research, 46(1), 59-77.

PEW Research Center, (2013). Global public opinion of Iran remains decidedly negative. Retrieved from: http://www.pewresearch.org/fact-tank/2013/09/23/global-public-opinionof-iran-remains-decidedly-negative/

Rao, M. (2000). Sanctions kill children in Iraq. Economic and Political Weekly. 
Rochefort D. A., \& Cobb, R. W. (1994). Problem definition: an emerging perspective. In D. Rochefort \& R. Cobb (Eds.). The politics of problem definition (pp. 1-31). Lawrence: University of Kansas Press.

Roe, E. (1994). Narrative policy analysis: Theory and practice. Durham, NC: Duke University Press.

Rogers, E. S. (1996). Using economic sanctions to control regional conflicts. Security Studies, 5(4), 43-72.

Shambaugh, G. E. (1999). States, Firms, and Power: Successful Sanctions in United States Foreign Policy. Albany: State University of New York Press.

Shultz, L. (2007). Educating for global citizenship: Conflicting agendas and understandings. Alberta Journal of Educational Research, 53(3).

Shultz, L., \& Jorgenson, S. (2008). Global citizenship education in post-secondary institutions: A review of the literature. Retrieved from: http://www.uofaweb.ualberta.ca/uai_globaleducation/pdfs/GCE_lit_review.pdf

Teicher, H., \& Teicher, G. R. (1993). Twin pillars to Desert Storm: America's flawed vision in the Middle East from Nixon to Bush. New York: William Morrow and Company.

Torbat, A. E. (2002). The brain drain from Iran to the United States. The Middle East Journal, 56(2), 272-295.

Torbati, Y. (2012). Iranian students feel the pain as currency collapses. Reuters. Retrieved from: Retrieved from: http://www.reuters.com/article/2012/10/17/us-iran-studentsidUSBRE89G10220121017

Trading Economics, (2013). Iran inflation rate. Retrieved from: http://www.tradingeconomics.com/iran/inflation-cpi

UK Oxfam Education, (2006). Education for global citizenship: A Guide for Schools. Retrieved from: http://www.oxfam.org.uk/ /media/Files/Education/Global\%20Citizenship/education_for _global_citizenship_a_guide_for_schools.ashx

UN Security Council Sanctions Committees, (2006). Security Council Sanctions Committees: An overview. Retrieved from: http://www.un.org/sc/committees/

United Nations, (2011). Human Rights for All. Retrieved from: http://www.un.org/en/globalissues/briefingpapers/humanrights/index.shtml 
Universal Declaration of Human Rights (UDHR). UDHR: United Nations. Retrieved from: http://www.un.org/en/documents/udhr/index.shtml\#ap

University of Pennsylvania, (2006).Trends by Region: Middle East and Penn's global engagement. Retrieved from: http://www.archives.upenn.edu/histy/features/intrntnl/country/mideast.html

University Portal, (2011). Accurate statistics of Iranian universities. Retrieved from: http://www.unp.ir/news_12377.htm\#

University Portal, (2013). 3\% budget cut in Iranian universities. Retrieved from http://www.unp.ir/news_30688.htm

Weiss, T. G. (1999). Sanctions as a foreign policy tool: Weighing humanitarian impulses. Journal of Peace Research, 36(5), 499-509. 